\title{
Regulatory Impact of Bank Performance in Nigeria: Application of Stochastic Frontier Analysis
}

\author{
Mustapha A. Akinkunmi \\ Correspondence: Mustapha A. Akinkunmi, Brickfield Road Associates Limited, 16, Akin Adesola Victoria Island Lagos, \\ Nigeria.
}

Received: December 6, 2016

doi:10.11114/aef.v4i4.2455

\author{
Accepted: March 15, $2017 \quad$ Available online: June 1, 2017 \\ URL: https://doi.org/10.11114/aef.v4i4.2455
}

\begin{abstract}
This study employs a panel dataset on the cost efficiency of Nigerian commercial banks to test the hypothesis whether internal regulation from the monetary authority affects the performance of commercial banks. The empirical work is carried out through the use of stochastic frontier analysis on 14 commercial banks over 10 years. The study finds that regulation has a negative and significant influence on the total cost while bank output, input prices and bank size have a positive and significant effect. This implies that the large the bank size, the higher total cost incurred.
\end{abstract}

Keywords: regulation, Nigeria's commercial banks, stochastic frontier analysis, bank performance

\section{Introduction}

Prior to the global financial crisis of 2008-2009, many banks realised huge profit through high leverage and/ or dependence on relatively cheap wholesale funding, as well as in some circumstances, elevated risk taking in form of estate lending or securitization. Variations in banks' behaviour and the dynamic regulatory framework made some most profitable business strategies less viable. In addition, the weak macroeconomic and financial market conditions led to worsening financial performance since the crisis. Therefore, in order to achieve a sustainable bank profitability and stability, banks have to adapt their appropriate business mix in line with the new operating environment. The new business climate emanated from several measures that have been put in place by the Nigeria's monetary authority to ensure a stable financial sector.

The main factors that influence the business model adjustment in the recent years are the regulatory reforms, market pressures, and changing risk-return preferences. The implementation of regulatory reforms as a result of the crisis has significantly influenced business models by including more high-quality capital, liquid assets, bailable debt and more stable funding sources in their bank balance sheets. However, the regulation poses an additional cost to trading activities, resulting in a fall in the number of activities the banks operate. Some regulations force banks to change their operating structures to new requirements, and trigger some business models to focus more on traditional banking activities. Second, owing to the market pressures, some banks involve low-margin activities to boost returns. Third, the changes in the business model capture their own initiatives in line with their altered risk-return preferences.

After the crisis, the banks focus more on retail banking (increase in retail funding and a reduction in non-retail assets) rather than investment banking and wholesale lending activities as experienced in the pre-crisis trend. In addition, several large banks reduced some wholesale lending activities like international leasing, trade finance and shipping, as well as commercial real estate.

The recent global shocks such as higher macroeconomic risks, declining commodity prices, uncertainty about rebalancing in China, and reduced confidence in policy traction, have significantly affect advanced economies, emerging economies and developing economies. For instance, many banks in developed countries are forced to push their bank valuation lower, as a result of a fall in equity prices and an increase in the credit spreads. In developing economies like Nigeria, the substantial decline in capital expenditures coupled with high private debt burdens poses a huge risk to sovereign balance sheets, markets and banks. This further retards growth, deters capital inflows and weakens exchange rate.

Owing to this, several policy measures that are put in place to boost aggregate demand and strengthen the financial system, remain ineffective as the risks emanated from slowing growth, remaining balance sheet vulnerabilities, tighter and more volatile financial conditions, have become more significant. The less accommodative monetary and financial 
conditions complemented with the spiked risk premiums and tighter financial conditions elevate the market and liquidity risks. The ability of policymakers to address the issue of market disruption and provide a stronger platform for growth and financial stability, has been questioned by financial markets.

However, there are still significance differences across banks in terms of cost efficiency as reflected by a wide range of cost-to-income ratios across Nigerian economy in 2015 (from 43\% to 70\%). Some banks respond to the increasing regulatory costs and other cost of complexity by engaging in business activities/ geographical regions in which they have sufficient economies of scale and better profit margins.

In the light of this, it is more important to understand the effect of regulatory measures on the performance of commercial banks as the country is struggling to move out of its economic recession. Therefore, this study intends to provide answers to the following research questions: how do regulatory measures affect the cost efficiency of commercial banks in Nigeria? What needs to be done to ensure financial stability that will stimulate the country's economic growth?

\subsection{Stylised Evidence of Nigerian Banking Sector}

Nigeria's economy grew at 3.05 percent for the first three-quarters of 2015 compared to 6.33 percent in 2014. Its low economic performance was as a result of continuous falling in the global crude oil price as well as reducing investors' confidence arose from the delay in creating a conducive business environment by the present administration, and the unstable condition of the exchange rate. In addition, the country experienced the worst with the negative growth rate for the first three-quarters of 2016.

Prior to the drastic fall in oil price that commenced in the mid-year of 2014, the Nigerian economy was driven by non-oil sector. However, the oil sector witnessed a declining growth rate towards the last quarter of 2014. This triggers government efforts towards reducing the over-dependence on the oil sector and diversifying the domestic economy.

The 2015 election posed a great uncertainty responsible for the unstable financial sector in replicating to a continuous rise in yields among all fixed income securities. Furthermore, the country witnessed a slow growth rate as a result of falling government revenue and foreign exchange scarcity. This led to the adoption of floating exchange rate in 2016 in order to halt the continuous depletion of foreign reserves. The cash reserve ratio (CRR) was also put at 31 percent for both public and private deposits; banks were prevented from accepting foreign cash deposits from their customers, and 41 items were officially removed from accessing foreign exchange at the official market rate. The monetary policy rate still remains 14 percent as at of January 2017.

Despite all these government measures, the country's external reserves reduced substantially from about US $\$ 35$ billion in 2014 to US\$ 28 billion in April 2016. This points to a reason against the continuous devaluation of the naira by economists. The Central Bank of Nigeria (CBN) put the official exchange rate at US\$1/305 in November 2016, even with the widely acceptable fact that floating exchange market might be the solution to the shortage of foreign exchange in the economy, a US\$1 is currently exchanged for about N500 in the parallel market.

\subsubsection{Contributions of financial Sector to Nigerian Economy}

Nigeria being the largest economy in Africa was recovering from commodity price shock of 2008-2009 as well as the banking crisis. Of recent, the country needs to address the issue of massive infrastructure deficits, and the high level of abject poverty and inequality. A sound banking system encourages more savings that can be channeled into productive investments, particularly in quality infrastructure. Thus, the contribution of the financial sector to the Nigerian economy was 3.51 percent in the third quarter of 2016 against 2.76 percent in the same quarter of 2015(Fig. 1).

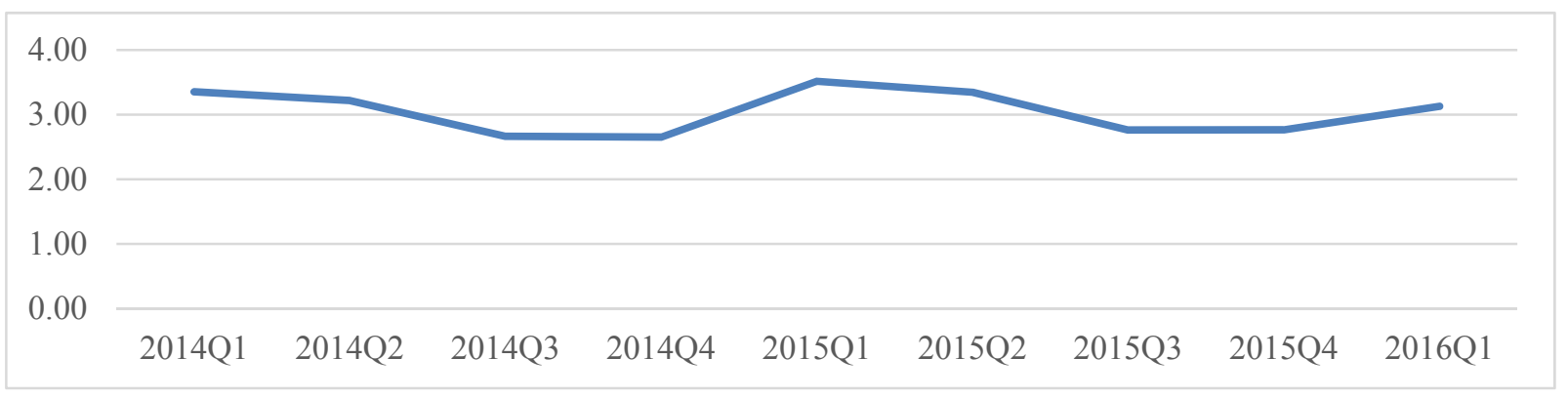

Figure 1. Contribution of Financial Sector to Nigeria’s Gross Domestic Products (\%)

Source: National Bureau of Statistics, Nigeria 2016 
Commercial banks are very important key players in the financial sector. For instance, the banks witnessed a peak growth rate of about 60 percent in their total assets at the end of 2005, indicating the positive outcome of the Nigeria's bank capitalization. However, the growth rate declined to the lowest in 2009 as a result of the 2007-2009 global financial crisis. Afterwards, an upward trend was recorded in their asset growth rate (Fig. 2).

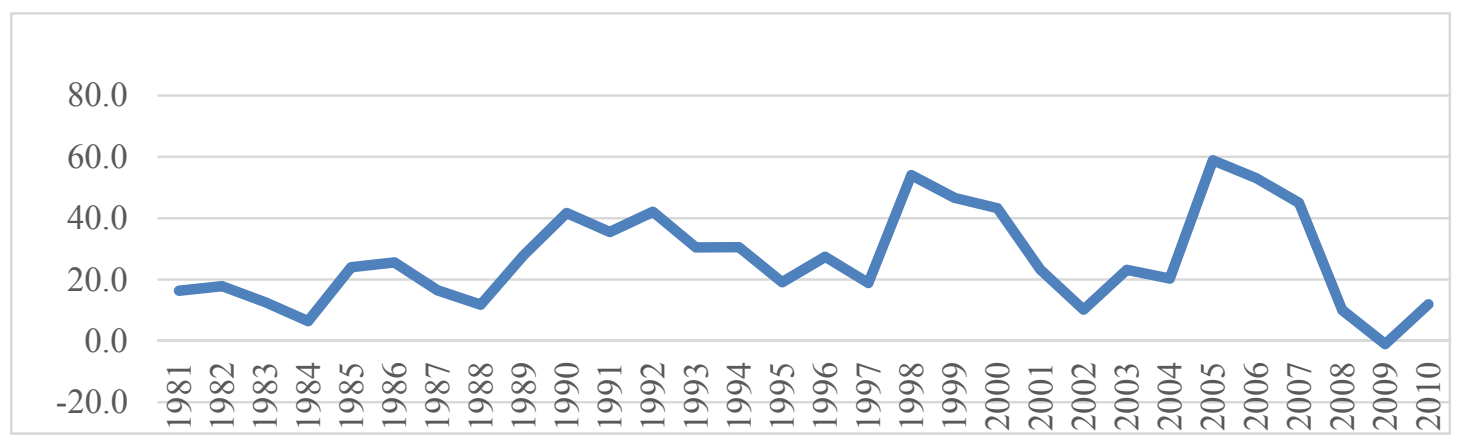

Figure 2. Annual Growth Rate of Commercial Bank's Assets in Nigeria (\%)

Source: CBN Annual Statistical Bulletin 2014

The sorry condition of Nigeria's oil sector has substantially created a high pressure on the banking system in the country. Banks confronted with the issues such as uncertainty before 2015 election; the implementation of the Treasury Single Account(TSA) which mops cheap government deposits from banks; higher level of non-performing loans arising from a drastic fall in oil prices; and the CBN's restrictive policies on foreign exchange, which hinders their lucrative foreign currency business.

Furthermore, the Nigerian banks are heavily dependent on oil and gas sector in the sense that about 23.8 percent of their loans is provided to the oil and gas sector in the first half of 2015 from 10 percent in 2014. The three largest banks in terms of asset raised their oil and gas portfolios by 101 percent, 47 percent, and 37 percent respectively in 2014 (Oxford Analytica). The recent sliding oil prices have negatively influenced banks' performance in the country. Therefore, this might significantly increase non-performing loans in most banks, which invariably could lead to low revenue and profits for them. Another issue is how honest banks are in disseminating their financial information on the Nigerian Stock Exchange.

Commercial banks in the country are running in an increasing unfavourable business environment as a result of an extreme fall in their profitability, asset quality, liquidity, and capital ratios. Their low performance is driven by their high exposure to their domestic market and the economic slowdown. The slowdown is attributed to lower oil prices, reduced government spending, and restriction on foreign exchange availability.

Since the execution of TSA in August 2015, public deposits which constitute about 8 percent of total deposit withdrew their money from commercial banks. This poses an added pressure to bank liquidity. Loan growth rate was contracted in mid-year of 2015 and non-performing loans were below 10 percent in 2015.

Some structural reforms have been implemented by developing economies like Nigeria in order to ensure that the banking sector is financially and efficiently healthy. The banking system in Nigeria was recorded better performance in the 1990s since there was adequate capital base in each bank to perform the financial operations. The sector experienced a high level of fragmentation complemented with a low level of financial intermediation at the end of 2014. This drives the banking sector reform by the Central Bank of Nigeria to raise the capital base of the banks from 2 billion naira to 25 billion naira, and invariably reduce the number of commercial banks from 89 to 25 through the process of mergers and acquisition in 2006(Hessen, 2007 as cited Gil-Alana et al.,2015). However, some of the 25 commercial banks were characterised with fund mismanagement and over-valuation of assets after CBN reform in 2006. This further reduced the number of banks to 22 (CBN, 2014 as cited in Gil-Alana et al., 2015).

A robust, stable and firmly anchored financial system is the key engine of a long-term sustainable economic growth. This is based on the fact that the banking industry provides required funds for carrying out production activities in the other sectors of the economy, as well as money needed by final consumers. Addressing this important and urgent issue motivates this study.

Effective and efficient operations of the financial sector are very critical in any economy because the financial sector especially commercial banks serve as a fuel for running economic activities. Therefore, more attention has been focusing on how well banks are running. This calls for numerous studies on what drives bank profitability within a country, a region, and at the global level. Similarly, many studies have been carried out for the Nigerian banks because of the country's specific features and its past experience. Nigerian banking industry experienced different reforms in order to ensure that the country has a strong banking industry that enhances the economic activities. This motivation led 
to the 2005 bank capitalization that reduced the number of commercial banks from 89 to 22 through merger and acquisition. However, scanty or little research have conducted on regulatory effects of bank performance in Nigeria. The aim of the study is to investigate the impact of regulation on bank performance. In order to achieve this, it specifically examines how regulatory measures influence cost efficiency of commercial banks and their implications on financial stability in Nigeria. The outcomes of this paper provide sufficient understanding to guide policymakers or government on how to improve the operations of commercial banks.

The rest of this study is sectionalized as follows; section II reviews the existing studies. The analytical framework, as well as methodology, are discussed in section III, while empirical results and discussion are presented in section IV. Section V concludes.

\section{Literature Reviews}

Based on the literature, the existing studies on determinants of bank profitability can be broadly grouped into two. The first stream of research examined factors that drive the level of profitability in a bank using cross-country data while the second stream examined the drivers through employing the country-specific data.

The first stream of research work includes Flamini et al.(2009), Titko et al.(2016), Petria et al.(2015), Djalilov and Piesse(2016), Bourke (1989), Short (1979), Pasiouras and Kosmidou (2007), Hsieh and Lee (2010), Molyneux and Thornton(1992), Ben and Omran (2011), Albertazzi and Gambacorta (2009). For instance, Djalilov and Piesse (2016) examined the factors that influence the level of bank profitability in transition economies particularly in Central and Eastern Europe between 2000 and 2013 for 275 banks using the generalised method of moments (GMM) technique. They found that credit risk positively and significantly determined bank profitability in the early transition but exhibited a negative impact in the late transition countries. The adverse relationship was found between governance and bank profitability, and between monetary freedom and bank profitability only in late transition economies. In addition, better-capitalized banks were more profitable in early transition countries.

However, Titko et al. (2016) conducted both multiple regression and correlation analyses to determine the drivers of bank profitability in Latvia and Lithuania from 2008 to 2014. Their findings indicated the absence of a significant link between net interest margin (measures profitability for Latvia), net commission and fees income as a percentage total assets (measure profitability for Lithuania), and independent variables.

Petria et al. (2015) employed panel data to analyse the determinants of bank profitability in the European Union between 2004 and 2011 with the aid of fixed effect and random effect models. Their result showed that bank profitability (returns on average assets and returns on average equity) received significant influence from credit and liquidity risk, management efficiency, the diversification of business, the market concentration/competition, and economic growth. However, bank size did not exhibit any significant influence on ROAE but had a small and weak significant impact in the case of ROAA. Furthermore, Ben and Omran (2011) examined the influence of bank regulation and financial reforms on banks' performance in MENA region by applying the dynamic system generalised method of moments (GMM) technique for the sample period 1988-2005. They found that the bank-specific variables particularly bank capitalization and credit risk exhibit a positive and significant impact on net interest margin, cost efficiency and profitability of banks, but no significant influence from macroeconomic and financial development variables. In addition, they identified that regulatory and institutional variables have an influence on bank performance.

In the same vein, Hsieh and Lee (2010) empirically addressed the puzzle between banking competition and profitability for 61 countries from 1992 to 2006 using the dynamic generalised method of moments (GMM) technique. They concluded that higher degree of activity restriction with the change in market structure boosts banks' profit; while restriction of commercial banks to involve in non-banking related activities, as well as an entry barrier for foreign banks, would weaken the positive link between banking competition and profit. In addition, the positive link might be weakening in economies with a sound financial system or high income per capita; and greater competition would mitigate the influence of banking competition on profit.

However, Albertazzi and Gambacorta (2009) investigated the link between business cycle fluctuations and banking sector profitability in selected 10 countries from Euro area and the Anglo-Saxon region between 1981 and 2003 using the generalised method of moments (GMM) estimator. Their findings indicated that gross domestic products (GDP) influenced both net interest income and loan loss provisions; and fluctuations of the long-term interest rate exhibited a slight impact on the net interest income in Italy, Spain and Portugal but a substantial impact recorded from the money market interest rate.

Similarly, Flamini et al. (2009) empirically examined the determinants of bank profitability in Sub-Saharan Africa between 1998 and 2006 using the panel data. With the aid of Arellano-Bond two-step Generalized Method of Moment(GMM), they found that variables such as bank size, activity diversification, and private ownership have a positive influence on the level of bank profitability(ROA) in the region. Also, their results revealed that returns on 
assets granger cause capital, implying that high returns are not instantly retained in the form of equity increases. On the other hand, Pasiouras and Kosmidou (2007) analysed the determinants of profitability in 584 commercial banks for selected fifteen European countries between 1995 and 2001 using a balanced panel dataset of 4,088 observations. They applied fixed effect estimation technique, and their findings indicated that all independent variables significantly influenced the level of profitability of both domestic and foreign banks. However, only the variable of concentration did not exhibit a significant influence in the case of domestic banks' profit.

Studies with a country-specific focus include Aburime (2008), Alkhazaleh and Almsafir (2014), Tariq and Usman (2014), Ani et al.(2012), Naceur and Goaied (2008), Mamatzakis and Remoundos (2003), Sufian and Habibullah (2012), Sufian and Habibullah (2010), Trujillo-Ponce (2013), Dietrich and Wanzenried (2010). Of recent, Boad (2015) investigated factors that determine the bank profitability in Ghana with the aid of random effect and pooled models from 1997 to 2014. He concluded that internal and external variables significantly determine bank profitability, unlike other studies, found evidence of significant influence from only non-interest income. In addition, no significant impact is recorded from variables such as the number of employees, inflation and real interest rate in Ghana.

Similarly, Alkhazale and Almsafr (2014) conducted an empirical analysis of determinants of bank profitability in Jordan between 1999 and 2013 using the fixed effect regression model. Their result showed that capital structure, bank size, and liquidity exhibit a significant influence on bank profitability. Tariq and Usman (2014) also analysed the determinants of profitability level among Pakistan banks for the sample period 2004-2010 by utilising both fixed and random effect models. However, Antonio (2013) investigated what determines the profitability of banks in Spain using data from 1999 to 2009 with the estimation technique of Generalised Method of Moments (GMM). He revealed that variables such as the percentage of loans in total assets, customer deposits, efficiency and low doubtful assets ratio positively affect bank profitability, but no effect of economies or diseconomies of scale, when profitability is captured by return on assets (ROA).

Sufian and Habibullah (2012) employed an unbalanced panel data of 153 banks to examine the effect of globalisation on bank performance in China with the aid of panel regression method. Their result revealed that bank profitability is positively and significantly determined by trade flows, cultural proximity, and political globalisation. On the other hand, Andreas and Gabrielle (2011) utilised unbalanced panel dataset of 372 commercial banks to examine the drivers of bank profitability in Switzerland before and during the global financial crisis with the application of the dynamic system GMM estimator. Their results revealed that capital ratio and credit quality exhibit no influence on bank profitability before the financial crisis but a negative and significant impact during the crisis. In addition, taxation significantly and negatively determines the level of bank profitability but market concentration (measured by Herfindahl Index) has a significant and positive influence before the crisis. Whereas, ownership and market structure do not have any impact on the level of profitability in the banking sector.

Sufian and Habibullah (2010) provided an empirical answer on whether economic freedom influences banks' performance in Malaysia using panel data between 1997 and 2007 with the OLS estimation technique. They found that economic freedom and business freedom have a favourable effect on banks' performance while an adverse effect comes from monetary freedom. They concluded further that corruption has a corrosive impact on Malaysian banks' profitability. However, Aburine (2008) analysed factors that influence the profitability level in Nigerian commercial banks using panel regression technique for the period 2000-2004. He revealed that bank profitability is significantly influenced by variables such as capital size, the size of the credit portfolio, extent of ownership concentration, while no significant impact was recorded from the size of deposit liabilities, labour productivity, and the state of IT ownership, control-ownership disparity, and structural affiliation. Similarly, Ani et al. (2012) utilised pooled ordinary least square (OLS) to investigate the drivers of bank profitability in Nigeria between 2001 and 2010. They found that bank size, capital and asset composition mainly affect the level of profitability (ROA, ROE, NIM) in Nigeria.

Based on the above literature reviews, it is obvious that little research has been carried out for Nigeria where commercial banks are so relevant for driving economic growth and development. In addition, the existing works found mixed and inconclusive results while none of the reviewed studies pays attention to the effect of 2005 bank capitalization in Nigeria. The need to fill this relevant gap motivates this study.

\subsection{Methodological Review on Regulation and Bank Efficiency}

Most empirical studies (Chortareas et al., 2012; Ben Naceur and Kandil, 2009; Ben Naceur and Omran, 2011; Pasirouras, 2008; Barth et al., 2001; Demirguc-Kunt et al., 2004) either employ accounting ratios or frontier approach to examine the effect of regulation on bank efficiency and performance.

Of recent, (2015) investigated the effect of banks' business model characteristics on bank stability using a dynamic panel model for 143 euro area banking groups over the sample period 1995-2014. In their model, bank risk is dependent variables while explanatory variables are bank-specific characteristics, macroeconomic and financial conditions, and 
structural market features. The bank risk is captured by Z-score which is defined as the sum of the return on assets and the equity-to-assets ratio over the standard deviation of returns on assets (computed using a five-year moving window). A number of bank-specific business model characteristics entail the retail ratio, an efficiency measure (cost-to-income ratio), a measure of income diversification (non-interest income over total revenue) a leverage ratio (equity-to-assets ratio) and size (the logarithm of total assets).

In addition, their results found that persistence of bank riskiness over time, and for the full sample period, larger banks and more retail-oriented banks are linked with lower default risk. Likewise, banks with more diversified income sources and more cost-efficient banks are generally less risky, and better-capitalized banks have lower default risk. Data are obtained from Bank scope, Bloomberg and SNL financial. The sub-sample periods are a pre-crisis period (2000-2007) and a crisis/ post-crisis period (2008-14).

Poghosyan and Kumbhakar (2010) applied a translog model to examine the cost efficiency of 681 banks in emerging economies for the sample period 1993-2004. Their findings based on a stochastic frontier techniques indicate that the average efficiency of 0.69. Similarly, Du and Girma(2011) estimated the cost efficiency model of 14 banks in China using the SFA between 1995 and 2001. They found that cost inefficiency ranges between 1.30 and 1.56. Other studies such as Williams (2012), Kumbhakar and Wang (2007); Manlagmit(2011); and Kasman and Yildirim(2006) also utilised the stochastic frontier analysis to estimating technical efficiency, cost efficiency and profit efficiency of banks in different countries. Williams (2012) estimated a profit efficiency of 0.50 in his work.

However, some research applied data envelopment analysis to estimate efficiency in terms of cost, technical, and profit (see Yildirim, 2002; Denizer et al., 2007, Ozkan-Gunay, 2012). Denizer et al.(2007) found that liberalisation did not improve the efficiency level of Turkish banks. Fukuyama and Matousek (2011) reported the positive effect of the restructuring program on bank efficiency for the sample period 2001-2004 with the application of two-stage network.

\section{Analytical Framework and Methodology}

\subsection{Analytical Framework}

This study applies a stochastic frontier analysis (SFA) to examine the influence of internal regulation on bank performance in Nigeria. The stochastic frontier method is initiated in the mid-1970s with the aim of estimating production functions, with a room for inefficiency among firms (see Aigner, Lovell and Schmidt, 1977; and Meeusen and Van dem Broeck, 1977). Numerous studies have employed to investigate banking efficiency. For instance, Berger and Mester(2001) for US banking; Mendes and Rebelo(1999) for Portugal; Griffell-Tatje and Lovell(1996) as well as Kumbhakar et al.(2000) for Spanish banking; Berg et al.(1993) for Nordic banking; and Kumbhakar and Sarkar(2003) for banking in India. Despite many efficiency types of research that focus on one country, little or scanty works have been conducted in developing nations like Nigeria.

Among the basic assumptions of the SFA approach is that firms in any economy do not always operate efficiently. Also, banks with similar features might not produce the same output, because of difference in their cost and profits. The differences arise from technical and/or allocative inefficiencies. For example, failure to attain the maximum possible output given the available inputs indicates technical inefficiency. On the other hand, allocative inefficiency denotes the inability in achieving the optimal allocation of inputs given input and output prices. This implies that the bank has not utilised the inputs in order to minimise costs. Both types of inefficiency pose a huge burden on the cost. The entire cost efficiency captures the decline in costs that can be achieved if a bank is both allocatively and technically efficient. In addition, it measures how close a bank cost is to what a best practice banks cost incurred in producing the same output bundle under the same conditions (Berger and Mester, 1997). The cost functions are difficult to observe directly. Therefore, inefficiency is determined against an efficient cost frontier. The SFA is employed in this study due to its ability to control for measurement error and other random effects. Unlike other SFA approaches, the Battese and Coelli(1995) SFA model estimates both the cost-frontier and the coefficients of the efficiency variables concomitantly. In addition, the $\mathrm{BC}$ model accommodates the unbalanced panel data in its estimation.

In order to observe the regulatory effects of the efficiency of the commercial banks, this study measures the cost efficiency of Nigerian commercial banks for the sample period 2001-2015. The nature and the scope of the data are influenced by data availability. Sheppard (1970) indicated how cost function can be derived from a product function and input prices. The cost function approach represents the dual of the production function approach. The cost function method is applied due to the easier estimation in multiple outputs unlike the production function approach with the assumption of a single output in the context of the SFA. In addition, the assumption of cost minimization is made in the cost function unlike output maximisation assumed in the production function approach. The cost function approach is more fitted in a competitive environment.

Based on this, the study adopts a cost function technique to estimate the effect of CBN regulation on the cost efficiency of commercial banks, with the use of a recent dataset. To the best of the author's knowledge, no study has been done on 
examining the regulatory effect on bank efficiency in Nigeria using a stochastic frontier analysis with the recent data.

In line with Aigner et al.(1997) and Meeusen and van den Broeck(1977), this study's stochastic cost frontier function can be specified as follows:

$$
C_{i t}=C\left(y_{i t}, w_{i t}, q_{t} ; \beta\right)+\exp \left(u_{i t}\right)+\exp \left(V_{i t}\right)
$$

Where $C_{i t}$ denotes the total cost of bank i incurs at time t, $y_{i t}$ is its output, $w_{i t}$ represents a vector of input prices, $\mathrm{q}$ is control variables and $\beta$ is a vector of all parameters to be estimated. $u_{i t}$ denotes inefficiency term which is independent identical distributed with a truncated normal distribution, while $V_{i t}$ captures measurement error and random effects, and is distributed as a standard normal variable. Both $u_{i t}$ and $V_{i t}$ are time and bank specific. Variables such as output and input price enter into the cost function while capital adequacy (CADE) and discount rate (DISC) are inculcated into the inefficiency equation.

This study implicitly assumes that banks have equal access to the same banking technology. In addition, a bank is regarded as inefficient if its costs outweigh those of an efficient bank rendering services under the same existing environment.

Different techniques have been applied in the literature to model the non-negative inefficiency component $u_{i t}$. This study utilises the true fixed effects model of Greene (2005), which considers time-invariant bank specific heterogeneity and time varying inefficiency separately by building bank specific dummy variables into the cost function. Based on this, it differentiates unobserved heterogeneity from inefficiency. However, in order to prevent an over specified cost function, the heterogeneity is integrated into the inefficiency distribution as suggested by Greene (2004). Therefore, time-varying inefficiency effect $u_{i t}$ is expressed as:

$$
\begin{gathered}
u_{i t}=\left|N\left(\mu_{i t}, \sigma_{u}^{2}\right)\right| \\
\mu_{i t,}=\xi_{i}+\eta^{\prime} z_{i t}
\end{gathered}
$$

Where $z_{i t}$ represents the vector of explanatory variables such as CADE and DISC that may affect bank inefficiency, $\eta$ is the vector of parameters to be estimated and $\xi_{i}$ is the bank specific intercept while $\sigma_{u}^{2}$ denotes the variance of inefficiency. The study assumes that $u_{i t}$ is a truncated-normal distribution with heterogeneous mean across banks. Therefore, cost efficiency for an individual bank is the ratio of the cost of the best practice firm having zero inefficiency and the cost of that bank. This can be written for the ith-bank at the $t$-th observation as:

$$
C E_{i t}=\exp \left(-u_{i t}\right)
$$

This makes the cost efficiency range between zero and one.

This study utilises a Cobb-Douglas cost function as observed in the literature for the cost frontier function as:

$$
\ln \left(\frac{c_{i t}}{w_{2 i t}}\right)=\beta_{0}+\beta_{1} \ln y_{i t}+\beta_{2} \ln \left(\frac{w_{k i t}}{w_{2 i t}}\right)+\sum_{i} \theta_{i} \ln q_{i t}+u_{i t}+v_{i t}
$$

Where $\ln C_{i t}$ denotes the natural logarithm of the total cost of the ith bank in period $\mathrm{t}, \ln y_{i t}$ is the natural logarithm of the output, $\ln w_{k i t}$ represents the natural logarithm of its kth input prices, $\ln q_{i t}$ captures a vector of control variables such as bank size.

The normalisation of costs and input prices by one of the input price $\left(w_{2 i t}\right)$ is done to impose linear homogeneity restriction. Then, the one-step maximum likelihood estimation approach is applied to estimate the parameters of the cost function and the inefficiency model. This method concomitantly estimates the stochastic cost function and the inefficiency correlates. In addition, it captures the possible correlation between the variables, influencing the cost function and the correlates of the inefficiency.

\subsection{Methodology}

This segment describes variables, sources of data and methodology.

\subsubsection{Variables and Sources of Data}

This study compiles its dataset from the Annual Financial Reports of 14 commercial banks in Nigeria from 2005 to 2014. The availability of data limits the study to choose 14 out of 20 Nigerian commercial banks, as well as the covered sample period. 
Table A.1. Variables Description

\begin{tabular}{llll}
\hline Symbol & Variables & Proxy & Data Source \\
\hline \multicolumn{2}{l}{ Dependent Variables } \\
Cost & Total Cost & Interest expenses+ Non-interest expenses & Annual Financial Reports \\
\multicolumn{2}{l}{ Explanatory variable } & & \\
SIZE & Bank Size & the logarithm of total assets & Bloomberg/Company's financials \\
CADE & Capital Adequacy & Equity/Total assets & Bloomberg/Company's financials \\
PRICES & Price of Physical capital and labour & Non-interest expenses/total expenses & Bloomberg/Company's financials \\
Y & Price of loanable funds & Total interest expenses/total deposit & \\
Regulatory factors (external) & Bank Output & Bloomberg/Company's financials \\
DISC $\quad$ Discount rate & Discount rate (annual \%) & World Development Indicator(WDI) \\
\hline
\end{tabular}

Note: All input and output prices are specified in Nigerian currency.

Source: Author's compilation

In line with the existing literature, this study identifies the potential efficiency correlates as capital adequacy, bank size and regulatory rate. Capital adequacy is included to capture regularity conditions. A prior expectation is that there is a negative link between inefficiency and capital ratio because a higher capital ratio indicates that banks are less risky and they can borrow at lower interest rates and have lower costs(Fries and Taci, 2005; Kumbhakar and Wang, 2007; Manlagnit, 2011).

In addition, the bank size is included in order to examine the impact of scale bias on inefficiency as observed in Hao et al. (2001), Demir et al. (2005) and Banker et al. (2011). Discount rate as a proxy for bank regulation is incorporated to investigate the influence of regulations on the cost efficiency of Nigerian commercial banks.

Hypothesis Testing

$H_{0}$ : Increase in regulation or unstable regulation leads to higher cost inefficiency in commercial banks.

$H_{1}: H_{0}$ is false.

\section{Empirical Results and Discussions}

The efficiency analysis mainly depends the choice of variables. Therefore, selecting the most important independent variables is significantly required in the efficiency analysis, since the exclusion of relevant variables could lead to wrong conclusions, while the inclusion of unnecessary variables might make the analysis chaotic, and interpretation difficult.

Based on this, the study specifies a set of potential efficiency correlates in the model, in line with the data availability. It investigates the degree of persistency in cost inefficiencies of commercial banks with the aim of providing an answer to whether an inefficient bank becomes efficient or remains inefficient over time.

As presented in Table 2, the mean of total cost records the highest while capital adequacy (CADE) accounts for the lowest expected value. Similarly, the lowest standard deviation is attributed to capital adequacy variable. This implies that there is a low level of uncertainty in the movement of the capital adequacy among the commercial banks (Table 2).

Table 2. Descriptive Statistics

\begin{tabular}{lllllll}
\hline Statistics & CADE & DISC & LN(COST) & LN(PRICES) & LN(Y) & SIZE \\
\hline Mean & 0.1423 & 10.3500 & 14.4342 & 3.0853 & 12.0530 & 5.6515 \\
Median & 0.1402 & 11.0000 & 14.6131 & 3.3708 & 12.4282 & 5.7933 \\
Maximum & 0.4052 & 13.0000 & 17.8927 & 6.2973 & 14.6138 & 6.6378 \\
Minimum & -0.3100 & 6.0000 & 9.5380 & -1.1545 & 7.0176 & 3.3423 \\
Std. Dev. & 0.0802 & 2.4408 & 1.6202 & 1.2448 & 1.5853 & 0.6517 \\
Skewness & -1.2765 & -0.7049 & -0.9088 & -1.8086 & -1.1115 & -1.2696 \\
Kurtosis & 10.8799 & 2.1784 & 3.7105 & 7.0740 & 4.0038 & 4.5802 \\
Jarque-Bera & 400.2233 & 15.5328 & 22.2145 & 173.1380 & 34.7026 & 52.1787 \\
Probability & 0.0000 & 0.0004 & 0.0000 & 0.0000 & 0.0000 & 0.0000 \\
Sum & 19.9255 & 1449.0000 & 2020.7940 & 431.9466 & 1687.4150 & 791.2129 \\
Observations & 140 & 140 & 140 & 140 & 140 & 140 \\
\hline
\end{tabular}

Source: Compiled by the Author

Table 3 summarises the results of stochastic cost frontier without any consideration for time effect. The results reported in the table suggest that bank output, input prices and bank size have a significantly positive influence on the total cost of operating commercial banks in Nigeria. However, capital adequacy and discount rate negatively affect the cost 
inefficiency incurred by Nigerian banks. It is only the variable of capital adequacy that is statistically significant at 10 percent. This is in line what is theoretically expected that the higher the capital adequacy growth, the lower the total cost inefficiency of the commercial banks in Nigeria.

On the other hand, central bank regulation through discount rate (DISC) has an insignificant negative effect on the measured banks' cost inefficiency. This supports the view that limiting bank activities reduces their income generating channels which lead to a reduction in their level of performance(or increase the total cost) as found in Barth et al. (2001). In addition, the study finds that the larger size of the bank increases the cost. This indicates that cost of running the large size outweighs the benefit derived from being large. Both inefficiency and random error terms have a positive and significant coefficient on the cost of running commercial banks in the country.

In order to capture the cost efficiency of Nigerian banks over time, the study investigates how the time influences the costs incurred. The results of Table 4 are obtained by adding time effect to the model of table 3 . The time term has a positive and significant coefficient while other independent variables have similar influence with what reported in Table 3 , except that discount rate is statistically significant. In addition, no significant impact comes from capital adequacy. Both inefficiency and random error terms have a positive and significant coefficient on the performance level of commercial banks in Nigeria. The coefficient impact of inefficiency on total cost incurred by Nigerian commercial banks reduces to about 0.523 under the time effect model. This implies that over time, the banks minimise their inefficiency or improve their cost efficiency.

Table 3. Estimation Result of Stochastic Cost Frontier with no time effect

\begin{tabular}{lcccc}
\hline Variable & Estimate & Std. Error & z value & $\operatorname{Pr}(>|\mathbf{z}|)$ \\
\hline $\begin{array}{l}\text { Dependent variable: } \\
\text { (Intercept) }\end{array}$ & 5.3740 & 0.6719 & 7.9983 & $1.2612 \mathrm{e}-15$ \\
$\begin{array}{l}\text { Explanatory variables } \\
\text { LN(INPUT PRICES) }\end{array}$ & 0.4229 & 0.0705 & 5.997982 & $1.9978 \mathrm{e}-09$ \\
LN (Y) & 0.3375 & 0.0823 & 4.103067 & $4.0771 \mathrm{e}-05$ \\
SIZE & 0.8664 & 0.2189 & 3.957953 & $7.5595 \mathrm{e}-05$ \\
CADE & -1.4277 & 0.7486 & -1.907236 & $5.6490 \mathrm{e}-02$ \\
DISC & -0.0303 & 0.0202 & -1.501338 & $1.3327 \mathrm{e}-01$ \\
Error components & & & & \\
sigmaSq & 0.9790 & 0.3352 & 2.9209 & $3.4906 \mathrm{e}-03$ \\
Gamma & 0.6593 & 0.1269 & 5.1960 & $2.0365 \mathrm{e}-07$ \\
\hline
\end{tabular}

Source: Compiled by the Author

Table 4. Estimation Result of the Stochastic Cost Frontier with time effect

\begin{tabular}{lcccc}
\hline Variable & Estimate & Std. Error & z value & $\operatorname{Pr}(>|\mathbf{z}|)$ \\
\hline $\begin{array}{l}\text { Dependent variable: Cost Frontier } \\
\text { (Intercept) }\end{array}$ & 7.4820 & 1.1139 & 6.7171 & $1.8534 \mathrm{e}-11$ \\
Explanatory variables & & & & \\
LN(INPUT PRICES) & 0.5544 & 0.0941 & 5.8905 & $3.8493 \mathrm{e}-09$ \\
LN (Y) & 0.2498 & 0.0906 & 2.7559 & $5.8522 \mathrm{e}-03$ \\
SIZE & 0.6085 & 0.2421 & 2.5129 & $1.1974 \mathrm{e}-02$ \\
CADE & -0.7068 & 0.8220 & -0.8598 & $3.8990 \mathrm{e}-01$ \\
DISC & -0.0419 & 0.0199 & -2.1056 & $3.5238 \mathrm{e}-02$ \\
Time effect & & & & \\
TIME & 0.1107 & 0.0500 & 2.2126 & $2.6927 \mathrm{e}-02$ \\
Error components & & & & \\
sigmaSq & 0.5227 & 0.1836 & 2.8464 & $4.4221 \mathrm{e}-03$ \\
Gamma & 0.4055 & 0.1982 & 2.0460 & $4.0761 \mathrm{e}-02$ \\
\hline
\end{tabular}

Source: Compiled by the Author

\section{Conclusion}

Nigeria's commercial banks witnessed a growth rate of 17.62 percent in terms of total bank loans and advances to the private sector at the end of first half of 2016, against a fall of 1.44 percent in the same period of 2015. The largest 
proportion of this credit went to the oil and gas sector. The recent poor performance of the oil and gas sector partly due to a decline in oil price and output has posed a tremendous challenge to the Nigerian economy and its financial stability. This led to different banking regulations by the monetary authority.

Therefore, this study aims to examine the influence of CBN regulation on the cost efficiency of commercial banks in Nigeria. The study utilises a panel dataset that covers 14 commercial banks to perform its analysis. It extends the frontier of research by investigating bank regulation in Nigeria that were not explored before in the literature using the stochastic cost frontier technique. In addition, it is the first research on the subject dedicated to Nigeria. It provides the first detailed analysis that examines how commercial banks' costs are affected by the CBN regulation.

The study finds that central bank regulation through discount rate is associated with reduced banks' cost inefficiency. It also finds that the banks' output (loans), the input prices and the bank size, have positive and significant effects on the total cost incurred by Nigeria's commercial banks. For instance, the higher level of input prices increases the total cost of the banks. The outcomes of the study exhibit strong policy implications as they underscore the need to address inefficiency and disturbance term arising from external factors such as exchange rate volatility and capital flights as they significantly contribute to the total cost of operating commercial banks in Nigeria.

However, there are enough rooms for further future research. One area of research is to examine the regulations and banks' cost efficiency by classifying the commercial banks into large and small size group. Another to be explored is to address the issue of unavailability of sufficient data in order to estimate the cost function and analyse it using efficiency tools. Quantifying the different categories of bank regulation and examining their effects on bank efficiency is another field of future research.

\section{References}

Aburime, T. (2008). Determinants of Bank Profitability: Macroeconomic Evidence from Nigeria. https://ssrn.com/abstract=1231064 or http://dx.doi.org/10.2139/ssrn.1231064

Aigner, D., Lovell, C., \& Schmidt, P. (1977). Formulation and estimation of stochastic frontier production function models. Journal of Econometrics, 6(1), 21-37. https://doi.org/10.1016/0304-4076(77)90052-5

Albertazzi, U., \& Gambacorta, L. (2009). Bank profitability and the business cycle. Journal of Financial Stability, 5(4), 393-409. https://doi.org/10.1016/j.jfs.2008.10.002

Alkhazaleh, A. M., \& Almsafir, M. (2014), Bank Specific Determinants of Profitability in Jordan. Journal of Advanced Social Research, 4(10), 1-20.

Ani, W. U., Ugwunta, D. O., Ezeudu, I. J., \& Ugwuanyi, G. O. (2012). An empirical assessment of the determinants of bank profitability in Nigeria: Bank characteristics panel evidence. Journal of Accounting and Taxation, 4(3), 38-43. https://doi.org/10.5897/JAT11.034

Banker, R. D., Chang, H., \& Seok-Young, L. (2011). Differential impact of Korean banking system reforms on bank productivity. Journal of Banking and Finance, 34(7), 1450-1460.

Barth, J. R., Caprio, G., \& Levine, R. (2001). Banking systems around the globe: Do regulations and ownership affect performance and stability? University of Chicago Press, 31-88.

Barth, J. R., Lin, C., Ma, Y., Seade, J., Frank, M., \& Song, F. M. (2013). Do bank regulation, supervision and monitoring enhance or impede bank efficiency? Journal of Banking \& Finance, 37, 2879-2892. https://doi.org/10.1016/j.jbankfin.2013.04.030

Battese, G. E., \& Coelli, T. J. (1995). A Model for Technical inefficiency effects in a stochastic frontier production function for panel data. Empirical Economics, 20, 325-332. https://doi.org/10.1007/BF01205442

Berg, S. A., Fosund, F. R., Hjalmarsson, L., \& Suominen, M. (1993). Banking efficiency in the Nordic countries. Journal of Banking \& Finance, 17(2-3), 371-388. Special Issue on the efficiency of financial institution. https://doi.org/10.1016/0378-4266(93)90038-F

Berger, A. N., \& Mester, L. J. (1997). Inside the black box: What explains differences in the efficiencies of financial institutions? Journal of Banking and Finance, 21, 895-947. https://doi.org/10.1016/S0378-4266(97)00010-1

Berger, A. N., \& Mester, L. J. (2003). Explaining the dramatic changes in performance of US banks: technological change, deregulation and dynamic changes in competition. Journal of Financial Intermediation, 12, 57-95. https://doi.org/10.1016/S1042-9573(02)00006-2

Bourke, P. (1989). Concentration and other Determinants of Bank Profitability in Europe. Journal of Banking and Finance, 65-80. https://doi.org/10.1016/0378-4266(89)90020-4 
Chortareas, G. E., Girardone, C., \& Ventouri, A. (2012). Bank supervision, regulation, and efficiency: Evidence from the European Union. Journal of Financial Stability, 8, 292-302. https://doi.org/10.1016/j.jfs.2011.12.001

Demirguc-Kunt, A., Laeven, L., \& Levine, R. (2004). Regulations, Market Structure, Institutions, and the Cost of Financial Intermediation. Journal of Money, Credit and Banking, 36, 593-622. https://doi.org/10.1353/mcb.2004.0045

Denizer, C., Dinc, M., \& Tarimcilar, M. (2007). Financial liberalization and banking efficiency: evidence from Turkey. Journal of Productivity Analysis, 27, 177-195.

Dietrich, A., \& Wanzenried, G. (2010). Determinants of Bank Profitability Before and During the Crisis: Evidence from Switzerland. https://ssrn.com/abstract=1370245 or http://dx.doi.org/10.2139/ssrn.1370245

Djalilov, K., \& Piesseb, J. (2016). Determinants of Bank Profitability in Transition Countries: What Matters Most? Research in International Business and Finance, 38, 69-82. https://doi.org/10.1016/j.ribaf.2016.03.015

Du, J., \& Girma, S. (2011). Cost economies, efficiency and productivity growth in the Chinese banking industry: evidence from a quarterly panel dataset. Emperical Economics, 41, 199-226.

Flamini, V., McDonald, C., \& Schumacher, L. (2009). The Determinants of Commercial Bank Profitability in Sub-Saharan Africa. International Monetary Fund, WP/09/15. https://doi.org/10.5089/9781451871623.001

Fukuyama, H., \& Matousek, R. (2011). Efficiency of Turkish banking: two stage network system. Variable returns to scale model. Journal of International Financial Markets, Institutions and Money, 21(1), 75-91.

Gil-Alana, Y. O. S., \& Adepoju, A. A. (2015). Fractional integration and structural breaks in bank share prices in Nigeria. Review of Development Finance 5 (1), 13-23. https://doi.org/10.1016/j.rdf.2014.07.004

Greene, W. (2004). Disiguishing between heterogeneity and inefficiency: stochastic frontier analysis of the World Health Organization's panel data on national health care systems. Health Economics, 13, 959-980.

Greene, W. (2005). Fixed and random effects in stochastic frontier models. Journal of Productivity Analysis, 23, 7-23.

Hao, J., Hunter, W. C., \& Kang, W. K. (2001). Deregulation and efficiency: the case of private Korean banks. Journal of Economics and Business, 53(2), 237-254.

Hsieh, M., \& Lee, C. (2010). The puzzle between banking competition and profitability can be solved: International evidence from bank-level data. Journal of Financial Services Research, Springer; Western Finance Association, 38(2), 135-157. https://doi.org/10.1007/s10693-010-0093-4

Kasman, A., \& Yildirim, C. (2006). Cost and profit efficiencies in transition banking: the case of new EU members. Applied Economics, 38(9), 1079-1090.

Kumbhakar, S. C., \& Lovell, C. A. K. (2000). Stochastic. Frontier Analysis, Cambridge University Press. https://doi.org/10.1017/CBO9781139174411

Kumbhakar, S. C., \& Sarkar, S. (2003). Deregulation, Ownership, and Productivity Growth in the Banking Industry: Evidence from India. Journal of Money, Credit and Banking, 35(3), 403-424. https://doi.org/10.1353/mcb.2003.0020

Lovell, C., \& Grifell-Tatjé, E. (1996). Profits and Productivity. Center for Financial Institutions, Working Papers from Wharton School Center for Financial Institutions, University of Pennsylvania.

Mamatzakis, E. C., \& Remoundos, P. C. (2003). Determinants of Greek Commercial Banks Profitability, 1989-2000. SPOUDAI, 53(1), 84-94.

Manlagmit, S. C.(2011). Cost efficiency, determinants, and risk preferences in banking: A case of stochastic frontier analysis in the Philippines. Journal of Asian Economics, 22, 23-35.

Meeusen, W., \& Broeck, J. (1977). Efficiency Estimation from Cobb-Douglas Production Functions with Composed Error. International Economic Review, 18(2), 435-444. https://doi.org/10.2307/2525757

Mendes, V., \& Rebelo, J. (1999). Productive efficiency, technological change and productivity in Portuguese banking. Applied Financial Economics, 9, 513-521. https://doi.org/10.1080/096031099332177

Molyneux, P., \& Thornton, J. (1992). Determinants of European Bank Profitability: A Note. Journal of Banking \& Finance, 16(6), 1173-1178. https://doi.org/10.1016/0378-4266(92)90065-8

Naceur, S. B., \& Goaied, M. (2008). The Determinants of Commercial Bank Interest Margin and Profitability: Evidence from Tunisia. Frontiers in Finance and Economics, 5(1), 106-130.

Naceur, S. B., \& Kandil, M. (2009). The impact of capital requirements on banks 'cost of intermediation and 
performance: case of Egypt. Journal of Economics and Business, 61, 70-89.

https://doi.org/10.1016/j.jeconbus.2007.12.001

Naceur, S. B., \& Omran, M. (2011). The effects of bank regulations, competition, and financial reforms on banks' performance. Emerging Markets Review, 12(1), 1-20. https://doi.org/10.1016/j.ememar.2010.08.002

Oxford Analytica. Daily brief on Finance. ttps://dailybrief.oxan.com/Sectors/Finance.

Ozkan-Gunay, E. N. (2012). Risk incorporation and efficiency in emerging market banks during he global crisis: evidence from Turkey, 2002-2009. Emerging Markets Finance and Trade, 48(5), 91-102.

Pasiouras, F. (2008). International Evidence on the Impact of Regulations and Supervision on Banks' Technical Efficiency: An Application of two-stage Data Envelopment Analysis. Review of Quantitative Finance and Accounting, 30(2), 187-223. https://doi.org/10.1007/s11156-007-0046-7

Pasiouras, F., \& Kosmidou, K. (2007). Factors influencing the profitability of domestic and foreign commercial banks in the European Union. International Business and Finance, 21, 222-237. https://doi.org/10.1016/j.ribaf.2006.03.007

Petria, N., Capraru, B., \& Ihnatov, I. (2015), Determinants of Banks' Profitability: Evidence from EU 27 Banking Systems. Procedia Economics and Finance, 20(15), 518-524. https://doi.org/10.1016/s2212-5671(15)00104-5

Poghosyan, T., \& Kumbhakar, S. C. (2010). Heterogeneity of technological regimes and banking efficiency in former socialist economies. Journal of Productivity Analysis, 33, 19-31.

Shepperd, R. W. (1970). Theory of cost and production functions. Princeton University Press, Princeton, New Jersey, $1-307$.

Short, B. (1979). The Relationship between Commercial Bank Profit Rates and Banking Concentration in Canada, Western Europe and Japan. Journal of Banking and Finance, 3(3), 209-219. https://doi.org/10.1016/0378-4266(79)90016-5

Sufian, F., \& Habibullah, M. S. (2010). Developments in the efficiency of the Thailand banking sector: a DEA approach. International Journal of Development Issues, 9(3), 226-245. https://doi.org/10.1108/14468951011073316

Sufian, F., \& Habibullah, M. S. (2012). Developments in the efficiency of the Malaysian banking sector: the impacts of financial disruptions and exchange rate regimes. Progress in Development Studies, SAGE Publishing, 12(1), 19-46. https://doi.org/10.1177/146499341101200102

Tariq, W., Usman, M., Mir, H. Z., Aman, I., \& Ali, I. (2014). Determinants of Commercial Banks Profitability: Empirical Evidence from Pakistan. International Journal of Accounting and Financial Reporting, 4(2), 2162-3082. https://doi.org/10.5296/ijafr.v4i2.5939

Titko, J., Skvarciany, V., \& Jurevičiene, D. (2015). Drivers of bank profitability: Case of Latvia and Lithuania. Intellectual Economics, 9(2), 120-129. https://doi.org/10.1016/j.intele.2016.02.003

Trujillo-Ponce, A. (2013). What determines the profitability of banks? Evidence from Spain. Accounting \& Finance, 53, 561-586. https://doi.org/10.1111/j.1467-629X.2011.00466.x

Williams, J. (2012). Efficiency and market power in Latin American banking. Journal of Financial Stability, 8(4), 263-276.

Yildirim, C. (2002). Evolution of banking efficiency within an unstable macroeconomic environment: the case of Turkish commercial banks. Applied Economics, 34, 2289-2301.

\section{Copyrights}

Copyright for this article is retained by the author(s), with first publication rights granted to the journal.

This is an open-access article distributed under the terms and conditions of the Creative Commons Attribution license which permits unrestricted use, distribution, and reproduction in any medium, provided the original work is properly cited. 